\title{
THE INFLUENCE OF CULTURAL HERITAGE ON THE ATTRACTIVENESS OF THE TOURIST DESTINATION
}

\author{
Mikhail A. Morozov', \\ Mikhail M. Morozov² \\ ${ }^{1}$ Plekhanov Russian University of \\ Economics, Moscow, Russia \\ ${ }^{2}$ Russian New University, \\ Moscow, Russia
}

\begin{abstract}
:
The issues of assessing the attractiveness of tourist destinations in the framework of cultural tourism are studied. It is shown that the presence of cultural heritage acts as the main, but not the only motivational factor when choosing a tourist destination of cultural tourism and forms a tourist need. The factors determining the attractiveness of the tourist destination for cultural tourism were studied. The classification of tourist attractiveness of destinations according to various signs is suggested: duration of its existence, degree of manageability by attractiveness. For cultural tourism it is offered to allocate and estimate three levels of attractiveness of the tourist direction: the existing appeal of the tourist destination, really achievable appeal and potential appeal. A model for assessing the attractiveness of a tourist destination is proposed, which allows to calculate the integral index of attractiveness depending on the availability of cultural heritage, development of tourist infrastructure, transport accessibility of the destination and other factors. The index of tourist destination attractiveness for cultural tourism allows to quantify the importance of this destination attractiveness and to carry out a comparative analysis of similar competing destinations.
\end{abstract}

\section{Keywords:}

Cultural tourism, tourist destination, tourist attraction, tourist destination attractiveness index

\section{INTRODUCTION}

In cultural tourism, the determining factor when choosing a tourist destination for a traveler is its attractiveness, which largely depends on the cultural heritage that this territory has. Tourist destination in this case can be called a territory of heritage. The key factor affecting the formation of tourist flows in the destination within the framework of cultural tourism is the attractiveness of the destination for tourists. Recently, many researchers have been studying the attractiveness of tourist destinations (Ritchie \& Zins, 1978, Krešić \& Prebežac, 2011, Lemaire \& Viassone, 2015). Conceptual approaches to quantifying the attractiveness of tourist destinations were studied in the works (Morozov et al., 2014, Morozov and Morozova, 2016). At the same time, the issues related to the assessment of the attractiveness of tourist destinations developing cultural tourism remain insufficiently researched. Particular attention should be paid to the factors that form
Correspondence:

Mikhail A. Morozov

e-mail:

mmorozov@bk.ru 
the realistically achievable and potential (strategic) attractiveness of the tourist destination in cultural tourism, which becomes an extremely important condition for the successful development of new tourist destinations (Morozov and Morozova, 2016).

\section{RESULTS}

The development of cultural tourism is carried out on the basis of those cultural and historical resources that the tourist territories possess. Tourist destinations are the territories of cultural heritage. The cultural heritage involved in tourism activities can be tangible and spiritual (immaterial) and includes:

- monuments - objects of architecture, monumental sculpture, paintings, archaeological objects, inscriptions, caves, which have outstanding value in terms of history, science and art;

- ensembles - groups of architectural buildings that stand out from an architectural point of view, along with landscapes, of great value from the point of view of history, science and art;

- places of interest - creations of man and (or) nature, of outstanding value in terms of history, aesthetics, ethnology or anthropology;

- customs, rituals, festivals, knowledge and skills related to traditional crafts, cultural spaces, etc.

To increase tourist flows to the destination within the framework of cultural tourism, it is necessary to identify the potential attractiveness that is the determining motivation for traveling, and then to strengthen and promote it. The following variants of attractiveness of tourist destinations are possible (Morozov and Morozova, 2016):

1. the attractiveness of a tourist destination can be formed spontaneously due to the wide popularity of those cultural and historical resources that are on its territory, that is, the historically existing cultural attraction of the tourist territory is a clear and obvious motive of travel;

2. the formation of the tourist attraction of the territory for cultural tourism is carried out purposefully on the basis of an assessment of its tourist and recreational potential, the potential attractiveness for tourists is determined, further, as the destination for cultural tourism is created and developed, this attraction is actively promoted among potential tourists.

Understanding the tourist attractiveness of the destination in terms of the development of cultural tourism makes it possible to formulate specific requirements for the tourist infrastructure and to ensure its creation. In the event that the tourist attractiveness of the destination meets the needs of cultural tourism, it is necessary to create an appropriate infrastructure for servicing tourist flows and provide information support to the newly created destination.

The main instruments for the formation of tourist territories are tourist destinations and tourist clusters. At the present stage, the formation of national tourist systems is based on the theory of cluster development of tourist territories (Morozov and Morozova, 2015). Tourist destination is characterized, above all, by its attractiveness from the point of view of the end user - a tourist. Tourist destinations, which have rich cultural, historical and other tourist resources, can generate different motives for travel, i.e. the attractiveness of this territory for tourists can be different. It is necessary to distinguish between the concept of the tourist potential of the territory and the tourist attraction. Tourist potential is characterized by the availability of tourist and recreational resources, which this territory possesses. Tourist attraction is that characteristic of a destination that is important for a tourist in terms of travel motivation and the possibility of meeting his tourist needs. In principle, there can be a situation where tourist attraction is very weakly dependent on the availability of tourist resources, for example, if it is event tourism.

Attractiveness of the tourist destination for cultural tourism is one of the most important factors affecting the formation of tourist flows. Tourist attractiveness is a complex integrated concept that can be described by a whole set of interrelated characteristics, including the availability of tourist and recreational resources, infrastructure support for destinations, information and advertising support for destinations. The attractiveness of the destination determines the motivation and purpose of the tourist's travel, forms a tourist need. 
We will highlight the factors that shape the attractiveness of the destination in terms of cultural tourism:

- the presence of cultural and historical tourist resources, national features of life, culture, etc., which have attractiveness for a potential tourist, forming a tourist interest, determining the purpose of travel and tourist expectations;

- transport and visa availability of tourist destination;

- socio-economic development of the destination, including the level of its economic and cultural development, prices for tourism goods and services;

- development of the general infrastructure of destination, including the state of public transport, the level of medical care, the availability of convenient car parks, etc .;

- availability and variety of tourist destination infrastructure, including accommodation and food for tourists, etc .;

- natural factors, including climate, ecological condition;

- information security of the tourist destination;

- security of stay in the destination;

- the attitude of the local population to tourists, etc.

One of the key parameters of the success of the tourist destination system is the return rate of tourists. When the tourist travels to the destination again, the attractiveness is characterized by the previously obtained tourist experience and the quality of tourist service. The evaluation of the quality of services is usually carried out in the form of a questionnaire (survey) of tourists. Recently, an online survey of tourists, for example, on the quality of service when visiting various attractions in different countries of the world.

The presence of cultural and historical resources, motivating the purpose of travel, is an important sign of the attractiveness of the tourist destination. With a quantitative and qualitative assessment of the attractiveness of the destination, it is necessary to take into account the type of tourism that develops in the given territory.

The availability of a tourist destination characterizes the real possibility of visiting a tourist destination and it can be characterized from different sides. It is necessary to distinguish the following varieties of accessibility of a tourist destination:

- transport (territorial) availability - availability and convenience of delivery of tourists to the destination and movement within the destination;

- Visa accessibility - simplicity and speed of visa formalities, including procedures for issuing entry and exit documents for foreign citizens;

- price accessibility - sufficient level of solvency of potential tourists wishing to visit the destination;

- information availability - availability of necessary and sufficient information for the tourist about this destination.

The availability and development of the tourist infrastructure depends to the maximum extent on the specifics of the types of tourism in the analyzed destination. When assessing the attractiveness of a tourist destination, this specificity must be taken into account when choosing those indicators that characterize the development of a specific tourist infrastructure.

The level of prices in the destination, including the tourism product itself and the related goods and services claimed by the tourist, plays an important role, but it is not always decisive. There is a certain category of tourists who choose a tourist product and destination regardless of the price of the tourist product, while the quality of the provided tourist services and the tourist attractiveness of the destination are the determining factors.

It should be noted that, taking into account the specific features of a particular type of tourism, the importance of these characteristics may be different and this must be taken into account when choosing indicators to assess the tourist attractiveness. For example, for extreme types of tourism, such as mountain tourism, territorial accessibility and the availability of tourist infrastructure may be less significant than the presence of unique natural landscapes. For some types of tourism, for example, eco or tourism for recreation, the nature and climate of the destination are decisive. 
Attractiveness of the tourist destination is proposed to be classified according to various criteria:

- sources of attractiveness (natural and climatic, historical and cultural, price and other factors generating tourist attractiveness of the destination);

- the duration of the existence of attractiveness (constant and temporary tourist attraction);

- the nature of the appearance of attractiveness (absolute and relative attractiveness);

- the degree of manageability of attractiveness (formed purposefully and accidentally arisen attractiveness).

The sphere of attractiveness is related to the kinds of tourism that develop in destinations, for example, natural and climatic factors give rise to attractiveness for ecological, rural, recreational tourism, and the availability of historical and cultural resources contributes to the development of cultural tourism.

By the duration of the existence of attractiveness, one should distinguish between constant attractiveness and temporary attractiveness. Constant attractiveness is associated, as a rule, with the availability of various sustainable tourist resources that exist for a long time, for example, natural and climatic conditions, cultural and historical sights, etc. Temporary attraction can be associated with any events (event tourism), for example, holding major international competitions, art exhibitions, festivals, which determine the attractiveness of the destination for a short period of time.

Absolute attractiveness exists in those destinations that have unique and non-reproducible tourist resources, for example, within the framework of cultural tourism, such tourist resources include archaeological sites. Attractiveness is relative if it can be created artificially in another tourist destination, for example, Disney entertainment parks.

The attractiveness of a tourist destination is an important criterion in assessing the competitiveness of destinations and is manifested in the possession of certain advantages and opportunities that allow to confront the destinations-competitors, in superiority over any parameter (factor) in the analyzed period of time (Morozov and Morozova, 2012).

Attractiveness of destination in tourism is most often associated with the fundamental principle of rarity, uniqueness, limited tourist resources. However, the fact that there are rare and unique tourist resources is not a real competitive advantage. Tourist resources are used in the places where they are located, tourists should be brought to the destination, where these tourist resources are located, and the necessary tourist infrastructure is a prerequisite. Thus, the tourist resource will become a real competitive advantage if the tourist infrastructure necessary for its effective use is formed.

We propose to distinguish three levels of attractiveness of a tourist destination:

1. the present attractiveness;

2. the attractiveness actually achievable in the foreseeable (short-term) period;

3. the potential (strategic) attractiveness that the destination can form in the long term.

The existing tourist attraction can be assessed using the questionnaire of tourists. At the same time, the questionnaire can be conducted both among tourists who have already visited the destination, to identify a return tourist flow, and among potential tourists for the forecast of tourist flows.

Evaluation of realistically achievable attractiveness can serve as a guide in the development of strategic plans for the development of tourist destinations and enhancing its attractiveness. At the same time, it is necessary to carry out an economic assessment of costs and calculate the economic effect from increasing the tourist attractiveness of the destination. The existence of an economic justification for assessing the feasible attractiveness of a tourist destination can serve as an incentive for attracting private investments in the implementation of tourism projects.

One and the same tourist territory can be attractive for tourists from different positions, that is tourist attractiveness of the destination can be multidirectional. In this case, when considering the attractiveness of a tourist destination, first of all, it is necessary to pay attention to the attractiveness that is the most significant and fundamental for the destination, that is, the one that generates the maximum tourist flows.

One of the most important characteristics of a really achievable attraction is the presence of a balanced tourist infrastructure in the destination. This means that in the tourist destination must be created in sufficient 
quantity and appropriate quality of the objects of tourist infrastructure, designed to serve tourists by types of tourism. The balance of the tourist infrastructure in the destination is one of the most important criteria by which they should be compared and evaluated for competitiveness.

\section{DISCUSSION}

It is advisable to evaluate not only the attractiveness of a tourist destination in general, taking into account all components of the tourism industry, but also to assess the attractiveness of a particular type of tourism in this destination.

Table I shows the factors that we propose to use when assessing the attractiveness of a tourist destination in terms of cultural tourism. Each factor is characterized by a set of indicators, and those in turn are characterized by a number of characteristics. This table was developed by the authors taking into account the specificity of cultural tourism.

Table I. Factors determining the attractiveness of a tourist destination for cultural tourism

\begin{tabular}{|c|c|c|}
\hline Factors & Indicators & Symptoms \\
\hline \multirow{8}{*}{$\begin{array}{l}\text { The presence of cul- } \\
\text { tural and historical re- } \\
\text { sources that have an } \\
\text { attractiveness for a po- } \\
\text { tential tourist, forming } \\
\text { a tourist interest, de- } \\
\text { termining the purpose } \\
\text { of travel and tourist } \\
\text { expectations }\end{array}$} & \multirow{5}{*}{$\begin{array}{l}\text { Cultural and } \\
\text { historical attractions }\end{array}$} & Cultural Attractions \\
\hline & & Architectural sights \\
\hline & & Historical places of interest \\
\hline & & Archaeological sites 1 \\
\hline & & Folk crafts, folklore \\
\hline & \multirow{3}{*}{ Events } & Conducting meaningful cultural events \\
\hline & & Conducting music and folklore festivals \\
\hline & & Gastronomic events in the light of national cuisines \\
\hline \multirow{12}{*}{$\begin{array}{l}\text { Availability of tourist } \\
\text { destination }\end{array}$} & \multirow{4}{*}{$\begin{array}{l}\text { Territorial } \\
\text { (transport) availability }\end{array}$} & Remoteness from the place of permanent residence of a tourist \\
\hline & & $\begin{array}{l}\text { A variety of modes of transport for the delivery of tourists to the } \\
\text { destination }\end{array}$ \\
\hline & & Average travel time \\
\hline & & Availability of direct delivery options \\
\hline & \multirow{4}{*}{ Visa Availability } & The need for visa or visa-free regime \\
\hline & & Simplicity of visa registration \\
\hline & & Terms of visa registration \\
\hline & & Cost of visa registration \\
\hline & \multirow{2}{*}{ Price accessibility } & The cost of a tourist product to the destination \\
\hline & & Cost of related services \\
\hline & \multirow{2}{*}{$\begin{array}{l}\text { Information } \\
\text { accessibility }\end{array}$} & Availability of necessary information on the destination \\
\hline & & Availability of information in a language accessible to tourists \\
\hline \multirow{4}{*}{$\begin{array}{l}\text { Infrastructure of } \\
\text { tourist destination }\end{array}$} & \multirow{2}{*}{$\begin{array}{l}\text { Infrastructure of } \\
\text { accommodation } \\
\text { facilities }\end{array}$} & Availability of hotels of a certain star \\
\hline & & Availability in the period of interest to the tourist \\
\hline & \multirow{2}{*}{$\begin{array}{l}\text { Infrastructure of } \\
\text { public catering }\end{array}$} & Presence of restaurants, cafes, etc. \\
\hline & & The tourist's interest in the national cuisine \\
\hline \multirow{2}{*}{$\begin{array}{l}\text { The price level in the } \\
\text { destination }\end{array}$} & $\begin{array}{l}\text { Price of main tourist } \\
\text { product }\end{array}$ & Price-quality ratio \\
\hline & $\begin{array}{l}\text { Price of related prod- } \\
\text { ucts and services }\end{array}$ & $\begin{array}{l}\text { The level of prices for goods and services purchased during the } \\
\text { journey }\end{array}$ \\
\hline
\end{tabular}




\begin{tabular}{|c|c|c|}
\hline \multirow{4}{*}{$\begin{array}{l}\text { Safety of stay in the } \\
\text { destination }\end{array}$} & \multirow{3}{*}{ Personal safety } & Crime rate in the destination \\
\hline & & Possibility of obtaining necessary medical assistance \\
\hline & & General ecological and epidemiological situation in the destination \\
\hline & Luggage safety, etc. & Safety of luggage in transport and in the hotel \\
\hline \multirow{2}{*}{$\begin{array}{l}\text { The comfort of a tour- } \\
\text { ist's stay in a destina- } \\
\text { tion }\end{array}$} & \multirow{2}{*}{$\begin{array}{l}\text { Attitude of the local } \\
\text { population to tourists }\end{array}$} & The degree of goodwill of the local population to tourists \\
\hline & & $\begin{array}{l}\text { Readiness of the local population for communication with the } \\
\text { tourist (knowledge of the language of communication) }\end{array}$ \\
\hline
\end{tabular}

It should be noted that the set of indicators can vary depending on the specifics of the destination and the type of tourism.

The attractiveness of the tourist destination is proposed to be assessed on the basis of expert estimates of tourists using the following model (Morozov et al., 2014).

Notation:

$\mathrm{Xi}$ - attractiveness of the destination according to the i-tourist's estimate, $\mathrm{i}=1,2 \ldots, \mathrm{I}$,

I - the number of tourists participating in the survey.

$\mathrm{Yj}$ - the indicators used to assess the tourist attractiveness of the destination, $\mathrm{j}=1,2, \ldots, \mathrm{J}$,

Yjpq - the levels of the assessments of characteristics, $q=1,2, \ldots, \mathrm{Q}$,

$\mathrm{p}=1,2, \ldots, \mathrm{m}$ - the number of characteristics characterizing the indicator,

$\mathrm{Rj}$ - weights.

Each indicator is assigned a weighting factor $\mathrm{Rj}$, which is determined expertly and characterizes the importance of the indicator in terms of attractiveness of the destination. To more accurately determine the individual characteristics of the indicator and its objective evaluation, each of the component indicators is divided into several characteristics Yjp, for which weights are also set and an evaluation scale (levels) is developed.

$$
\mathbf{F}\left(\mathbf{X}_{\mathrm{i}}\right)=\sum_{\mathrm{j}} \sum_{\mathrm{p}} \sum_{\mathrm{q}} \mathbf{Y}_{\mathrm{jpq}} \leq \mathbf{1 0 0 0}, \forall \mathbf{i}
$$

Weights weighting coefficients $\mathrm{Rj}$ are set so that the total sum of all weights is equal to $100 \%$ (1000 points).

$$
\sum_{j} \mathbf{R}_{j}=100 \%, \sum_{j} \mathbf{R}_{j}=1000 \text { баллов }
$$

The weight coefficients of attributes are determined by the formula:

$$
\begin{aligned}
& \sum_{p} \mathbf{r}_{p}=\mathbf{R}_{j} \sum_{p} \mathbf{r}_{p}=100 \% \\
& F\left(X_{i}\right)=\sum_{j} \sum_{p} \sum_{q} Y_{j p q} \leq 1000, \forall i,
\end{aligned}
$$

where $\mathrm{F}(\mathrm{Xi})$ is the number of points determined by the $\mathrm{i}$ - th tourist,

$$
\mathbf{F}(\mathbf{X})=\sum_{\mathbf{i}} \mathbf{F}\left(\mathbf{X}_{\mathbf{i}}\right)
$$

$\mathrm{F}(\mathrm{X})$ - the total amount of points for the destination, which was estimated by tourists.

The index of attractiveness of tourist destinations is calculated by the formula:

$$
I_{\text {пд }}=\frac{F(X)}{I}
$$


The index of attractiveness of the tourist destination allows you to quantify the significance of the attractiveness of the destination and make a comparative analysis of similar competing destinations.

\section{CONCLUSION}

The successful development of cultural tourism is associated with the correct identification of the attractiveness of tourist destinations and the presence on its territory of cultural heritage, which determines the main motivation of tourists. However, the presence of cultural and historical resources is a necessary, but insufficient condition for the development of mass cultural tourism. Servicing tourists requires the creation of an appropriate tourist infrastructure.

The formation of the tourist attractiveness of the destination must be oriented towards satisfying those tourist needs that determine the motivation of travel. In addition, it is necessary to provide information support and promotion of tourist attraction of destination, that is, to convey information to a potential target audience of travelers. Tourist destinations can develop several types of tourism and, accordingly, have different attractiveness. The main attraction will be the one that generates the maximum tourist flows. The unique attractiveness of a tourist destination can be its key competitive advantage.

For cultural tourism, it is proposed to distinguish three levels of attractiveness of a tourist destination: existing, realistically achievable and potential (strategic) attractiveness. Such a level consideration of attractiveness will help to plan correctly the strategic development of the tourist destination. To quantify the attractiveness of the tourist destination it is proposed to use the index of attractiveness, which is calculated on the basis of expert estimates of tourists. This will provide a comparative analysis of competing tourist destinations.

\section{REFERENCES}

Krešić, D., \& Prebežac, D. (2011). Index of destination attractiveness as a tool for destination attractiveness assessment. Tourism, 59(4), 497-517.

Lemaire, J.P., \& Viassone, M. (2015). Tourist Destinations Positioning: From Indexes to Managerial Implications. Journal of Investment and Management, Special Issue: Attractiveness and Governance of Tourist Destinations, 4(1-1), 30-38.

Morozov, M.A., \& Morozova, N.S. (2015). Forming a system of indicators for assessing the effectiveness of the regions in the tourism industry. Sochi Journal of Economy, 2 (35), 105-115.

Morozov, M.A., \& Morozova, N.S. (2016) Attractive Tourist Destinations as a Factor of its Development. Journal of Environmental Management and Tourism, 7, 1 (13), 105-112. DOI:10.14505 / jemt.v7.1 (13) .10.

Morozov, M.A., \& Morozova, N.S. (2012) Evaluation of the attractiveness of tourist destinations. Bulletin of the Russian State University of Trade and Economics, 7-8 (67), 41-49.

Morozov, M.A., Morozova, N.S., Karpova, G.A., \& Khoreva, L.V. (2014). Tourism Economics. Moscow: Federal Agency for Tourism.

Ritchie Brent, J.R., \& Zins, M. (1978). Culture as Determinants of the Interest in the Tourism Region. Annals of Tourism Research, April-June. 